\title{
Buddhism, euthanasia and the sanctity of life
}

\author{
Roy W Perrett Massey University, Palmerston North, New Zealand
}

\begin{abstract}
Damien and fohn Keown claim that there is important common ground between Buddhism and Christianity on the issue of euthanasia and that both traditions oppose it for similar reasons in order to espouse a "sanctity of life" position. I argue that the appearance of consensus is partly created by their failure to specify clearly enough certain key notions in the argument: particularly Buddhism, euthanasia and the sanctity of life. Once this is done, the Keowns' central claims can be seen to be either false or only restrictedly true.
\end{abstract}

\section{Introduction}

Damien and John Keown claim that there is important common ground between Buddhism and Christianity on the issue of euthanasia and that both traditions oppose it for similar reasons in order to espouse a "sanctity of life" position. " More particularly, they claim that the following five conclusions may be drawn about euthanasia in Buddhism and Christianity. First, that despite their cultural and theological differences, there is a striking similarity in the two religions' opposition to the intentional killing of patients. Second, this opposition derives from their shared rejection of consequentialist reasoning in favour of an ethical approach grounded in a respect for life as a basic as opposed to an instrumental good. Third, notwithstanding their absolute opposition to euthanasia, both religions teach that life is not an absolute value to be preserved at all costs and emphasise the transitoriness of earthly life. Fourth, this consensus challenges prevalent assumptions about the impossibility of moral consensus in the modern world. Fifth, this consensus lends support to the conviction that a common set of core values may be found in the teachings of the world religions. ${ }^{2}$

The ecumenical spirit of these conclusions may be uplifting, but their truth, I shall argue, is rather more dubious. Moreover, the appearance of consensus

\section{Key words}

Death and dying; religious ethics; Buddhism; euthanasia; sanctity of life. between the two traditions is partly created by the Keowns' failure to specify clearly enough certain key notions in the argument: particularly Buddhism, euthanasia and the sanctity of life. Once this is done, the claims above can be seen to be either false or only restrictedly true.

\section{Euthanasia}

Euthanasia is "mercy killing". More formally, it is the killing of those who are incurably ill and in great pain or distress, where the killing is done for the sake of those killed, and in order to spare them further suffering or distress. This motivation distinguishes euthanasia from most other forms of taking life Euthanasia can take three forms: voluntary, involung tary and non-voluntary. Euthanasia is voluntary when it is carried out at the request of the person killed. Sometimes this may be scarcely distinguishable from assisted suicide; other times people wanting to die may be physically incapable of killing themselves. Euthanasia is involuntary when the person killed is capable of consenting to her own death but does not do so. Euthanasia is nonvoluntary when the subject is unable to consent: for instance, because she is a severely handicapped infant, or because she is an irreversibly comatose adult who has omitted to specify previously how she wished to be treated in such an eventuality.

All three kinds of euthanasia can be either active or passive. Active euthanasia typically involves a deliberate act which results in the patient's death (for example, administering a lethal injection). Passive euthanasia involves a deliberate omission (for example, withdrawing or withholding life-sustaining treatment).

What do the Keowns understand by "euthanasia"? They explain themselves thus: "By 'euthanasia' we mean the intentional killing of a patient by act or omission as part of his or her medical care. We are not concerned, therefore, with either the administration of palliative drugs, or the withdrawal of futile or excessively burdensome treatment, which may, as a foreseen side-effect, hasten death". ${ }^{3}$

Given this gloss on "euthanasia" it seems the Keowns hold that both Buddhism and Christianity 
reject euthanasia in its voluntary, involuntary and non-voluntary forms. They also apparently include in this rejection both active and passive euthanasia, since they concede that omissions as well as acts can constitute euthanasia. However, they clearly feel too that some version of the doctrine of double effect enables them to exclude as cases of euthanasia certain acts and omissions, the foreseen but unintended consequences of which, will be the patient's death. Thus, although Buddhism and Christianity are both supposed to be opposed to euthanasia, neither is thereby committed to life being an absolute value to be preserved at all costs.

\section{The sanctity of life}

It is often rather unclear just what is meant by an appeal to "the sanctity of life" in bioethical disputes. In the bioethical literature nowadays, however, it is usually assumed that the doctrine of the sanctity of life is roughly the claim that all human life is of equal intrinsic value. Accordingly, except in cases of the legitimate defence of others' lives, it is always intrinsically wrong to take human life (though it may sometimes be permissible to let someone die). ${ }^{4}$

The Keowns express concern about the frequent misrepresentation of the doctrine of the sanctity of life. But their own explanation of it is unfortunately not as clear as it might be, for they offer several, apparently logically distinct, formulations of it. These include the following four theses:

(1) That as life is a gift from God, it is to be cherished.

(2) All human beings are to be valued, irrespective of age, sex, race, religion, social status or their potential for achievement.

(3) The deliberate taking of human life is prohibited except in self-defence or the legitimate defence of others.

(4) Human life is a basic good as opposed to an instrumental good, a good in itself rather than as a means to an end. ${ }^{5}$

Obviously these four formulations are not logically equivalent, and the supposed relations of implication between them are unspecified. But presumably for the Keowns, affirming the sanctity of life doctrine at least involves affirming one or more of (1)-(4). The Keowns quickly acknowledge that (1) would be denied by Buddhism as a corollary of its denial of a creator God. Instead, Buddhism's purported belief in the sanctity of life "is grounded not in its divine origin but in its spiritual destiny, namely the state of final perfection known as nirvana". ${ }^{6}$

\section{Buddhism}

Trying to make plausible general descriptive claims about Buddhism's attitudes to euthanasia presents us with a number of difficulties. Firstly, there is the relative paucity of explicit Buddhist discussions of this or other bioethical issues. ${ }^{7}$ Accordingly, most of the burgeoning secondary literature in this area is reconstructive or speculative to varying degrees. Secondly, there are many schools of Buddhism and no central authority on matters of precept or practice.

The Keowns do not see a problem with this second issue. This is because they claim that there is "a consensus on ethics among the main schools" and that for the purposes of their article it is permissible to take the Theravāda tradition, "the oldest and most orthodox of the surviving traditions", as representative of the Buddhist position. ${ }^{8}$ This procedure, however, just slides over a number of important questions in a quite unacceptable way.

In the first place it is not at all clear that there is a consensus on ethics among the main Buddhist schools, especially on this issue. Even if we confine ourselves only to Indian Buddhism, there are significant differences between the ethics of the Mahāyāna and the Hinnayāna, as Damien Keown himself admits elsewhere. ${ }^{9}$ When we come to consider the Buddhist traditions of Tibet, China and Japan we find still further differences. Moreover, since the Keowns suggest that part of the interest of their comparison lies in the fact that Buddhism is an influential religion with roughly 500 million Asian adherents, ${ }^{3} 8$ it is worth remarking that the vast majority of these persons are Mahāyānists. While the Theravāda mayç indeed be the oldest surviving Buddhist school, it is? quite incorrect to suggest that it is the "most orthodox" if by that is meant (as the dictionary definition of "orthodox" would suggest) that it holds correct or unheretical religious doctrines. Theravādin doctrines and texts have no authority in Mahāyāna Buddhism.

In the second place we need to be clearer about what sort of evidence is adduced in support of descriptive claims about Buddhism. The Keowns' claims about Theravāda Buddhism rely on certain canonical Pali texts. Observers report, however, that sanctioned Buddhist practice in the Theravāda lands is often rather different. ${ }^{10}$ Why valorize the textual, rather than the contextual, tradition in making general claims about Buddhism? Certainly truths about Buddhism which are based entirely on certain normative monastic texts can have at best restricted scope.

Finally, the nature of the Theravāda texts that are utilised by the Keowns needs to be understood. They rely on the Vinayapitaka, the case books of monastic discipline. However, rather than enunciating general principles from which particular judgments can be derived, the Vinaya prefers extensive listing of individual cases and the Buddha's reported judgment thereon, often making it difficult to see what the ratio of the particular judgment might be. Moreover it is important to realise that the cases involve breaches of monastic discipline. Thus the Keowns correctly claim that various cases of killing, 
and even inciting to suicide, are condemned in the Vinaya as unsuitable activities for monks, meriting the stringent penalty of pāräjika. But this penalty is not "lifelong excommunication", as the Keowns gloss it. ${ }^{6}$ It is simply expulsion from the monastic order, not from the Buddhist community. Moreover a monk can also suffer a similar fate for three other offences: sexual intercourse, theft, and falsely claiming superhuman powers. The special ethical demands on monks are obviously rather more rigorous than those on Buddhist laypersons.

\section{Five claims reconsidered}

With these distinctions in mind, I want now to reconsider the Keown's five claims about Buddhism and euthanasia.

(i) Buddhism and Christianity are united in their opposition to euthanasia. I am only concerned with the Buddhist component of this assertion, which as a general claim is surely false. Buddhists (like most bioethicists, secular and religious) probably generally oppose involuntary euthanasia. But there are Buddhist traditions sympathetic to both voluntary and non-voluntary euthanasia, under certain conditions.

Since voluntary euthanasia often amounts to assisted suicide, it is important to recognise that Buddhist attitudes to suicide have always been much less harsh than Christian ones. Suicide from despair has been seen in Buddhism as a prudential error since, given their unresolved karma, suicides will just be reborn in situations similar to those they were seeking to escape from. Even in the Pali canon, however, properly motivated suicides of monks are permissible. ${ }^{11}$ In the Mahāyāna Buddhism of East Asia these tendencies become much more emphasised, ${ }^{12}$ with this tradition coming to some prominence in the 1960 s because of the politically motivated self-immolations of certain Vietnamese monks. Moreover, there developed in Japan a wellknown cult of morally approved ritual suicide (seppuku or, more vulgarly, harakir), including the use of an attendant (kaishaku) who assists the suicide by beheading him after he has stabbed himself, in order to minimise his suffering. ${ }^{13}$

Traditional Japanese attitudes to the nonvoluntary euthanasia of infants are also quite permissive. Midwives would not assume that a new-born baby should live, but would ask if the infant was "to be left" or "to be returned". Defective infants were regularly subject to "thinning" (mabiki). ${ }^{14}$ Just as a tolerance for, and ritualisation of, abortion evolved in Japanese Buddhism, ${ }^{15}$ so too did a tolerance for, and ritualisation of, euthanasia under certain circumstances.

Tibetan Buddhism seems rather less tolerant of abortion. ${ }^{16}$ However, the Dalai Lama himself has indicated that euthanasia may sometimes be permissible: "In the event a person is definitely going to die and he is either in great pain or has virtually become a vegetable, and prolonging his existence is only going to cause difficulties and suffering for others, the termination of his life may be permitted according to Mahayana Buddhist ethics". ${ }^{17}$ And the late Kalu Rinpoche, a very senior Kagyu lama, said clearly both that persons who are terminally ill and decide to take themselves off life-support perform a "karmically neutral act", and that assisting a dying person who asks us to remove life-support is also karmically neutral, provided our basic motivation is to relieve the patient's suffering. ${ }^{18}$

All of this is not, of course, to deny that some Buddhists may indeed oppose euthanasia. ${ }^{19}$ But there is no general Buddhist consensus on this stand, particularly in the Mahāyāna traditions.

(ii) Buddhist and Christian opposition to euthanasia derives from a shared rejection of consequentialist reasoning in favour of an approach that respects human life as a basic, not an instrumental good. Again I dispute the Buddhist part of this claim. Although Buddhist ethics emphasises the importance of the agent's intentions or motives, it is also arguably strongly consequentialist, especially in its Mahāyāna forms. ${ }^{20}$ Consequentialism as a theory of the right holds that actions are right insofar as they promote the good. ${ }^{21}$ For Buddhists this good is the elimination of suffering (duhkha). Motives too are important in Buddhist ethics, but consequentialists can admit the importance of motives, provided the goodness of a motive depends on how good its overall consequences are. ${ }^{22}$ For Buddhists this means that the goodness of a motive depends on whether it promotes the elimination of suffering. Thus we can find even canonical Theravādin texts which affirm that whatever action, bodily, verbal, or mental, leads to suffering for oneself, for others or for both, that action is bad; while whatever action, bodily, verbal, or mental, does not lead to suffering for oneself, for others or for both, that action is good. ${ }^{23}$

Accordingly Buddhism does not value human life as an intrinsic good. It is true that the extreme rarity and preciousness of a human birth is often emphasised in Buddhism, especially in the Tibetan tradition. But the preciousness of a human birth is because only as a human is it possible to practise the dharma successfully and achieve the goal of the elimination of suffering, ie nirvāna. ${ }^{24}$

Nor does Buddhism affirm anything significantly like the Christian doctrine of the sanctity of life. Consider again theses (1)-(4) above, which the Keowns themselves offer as glosses of the doctrine. Buddhism actually denies both (1) and (2). (3) is too narrow as a formulation of the traditional sanctity of life doctrine, and anyway (as we have seen) there are Buddhist exceptions to it. Since (2) does not indicate how much every human is to be valued, it is so weak a formulation of the doctrine of the sanctity of life as to be inoffensive not only to the Buddhist, 
but even to the dreaded utilitarian bioethicist, who also, after all, opposes wanton killing.

Consider instead the following thesis which seems to capture better an important part of the traditional Christian understanding of the sanctity of life doctrine and its resistance to quality of life tradeoffs:

(5) All human life is equally valuable and inviolable. Does Buddhism affirm this (as, many claim, Christianity does)? Apparently not, for even the authoritative Theravādin commentator Buddhaghosa writes: "In the case of humans the killing is the more blameworthy the more virtuous they are". ${ }^{25}$

(iii) Both Buddhism and Christianity teach life is not an absolute value to be preserved at all costs and emphasise the transistoriness of life. Agreed, though Buddhism's reasons for this are significantly rather different. Most importantly, however, Buddhism (unlike Christianity) does not have to try to square this claim with the sanctity of life doctrine since Buddhism does not affirm the latter doctrine in any form close to a Christian understanding of it. Accordingly Buddhism does not have the same pressure to espouse philosophically dubious notions such as the doctrine of double effect, the distinction between "ordinary" and "extraordinary" treatment, or the claimed intrinsic moral difference between acts and omissions.

(iv-v) The consensus of Buddhism and Christianity about euthanasia both challenges pessimism about the possibility of moral consensus and supports the conviction that the world religions share a common core of values. Since the supposed general consensus about euthanasia does not exist, the optimism expressed in these claims remains to be justified.

Roy $W$ Perrett is Senior Lecturer in Philosophy in the Philosophy Department of Massey University, Palmerston North, New Zealand.

\section{References and notes}

1 Keown D, Keown J. Killing, karma and caring: euthanasia in Buddhism and Christianity. Fournal of Medical Ethics 1995; 21: 265-9.

2 See reference 1: 268 .

3 See reference 1: 265 .

4 On this understanding of the sanctity of life doctrine see, for instance, Glover J. Causing death and saving lives. Harmondsworth: Penguin, 1977; Kuhse $\mathrm{H}$. The sanctity-of-life doctrine in medicine: a critique. Oxford: Clarendon Press, 1987.

5 See reference 1: 267.

6 See reference 1: 266 .

7 There is, however, a growing secondary literature on these issues. For a useful (but by no means exhaustive) bibliographical review see Hughes J, Keown D. Buddhism and medical ethics. Fournal of Buddhist Ethics 1995; 2: 105-24.

8 See reference $1: 268$, n. 3 .

9 Keown D. The nature of Buddhist ethics. New York: St Martin's Press, 1992: ch. 6.
10 On Sri Lanka, for instance, see Gombrich R. Precept and practice. Oxford: Clarendon Press, 1971; on Burma see King W. In the hope of nibbana. LaSalle: Open Court, 1964, and Spiro M. Buddhism and society. New York: Harper, 1970.

11 See Wiltshire $M$. The "suicide" problem in the Pali Canon. Fournal of the International Association of Buddhist Studies 1983; 6: 124-40; Lamotte E. Religious suicide in early Buddhism. Buddhist Studies Review 1987; 4: 105-18. The Keowns admit this point (see reference 1: 268 n. 13), but try to play down its significance. See also Keown D. Buddhism and bioethics. New York: St Martin's Press, 1995: 58-60.

12 See Jan Y. Buddhist self-immolation in medieval China. History of Religions 1965; 4: 243-68; Rahula W. Zen and the taming of the bull. London: Gordon Fraser, 1978: 111-4.

13 Seward J. Hara-kiri: fapanese ritual suicide. Rutland: Charles E Tuttle, 1968; Kakubayashi F. A historical study of harakiri. Australian fournal of Politics and History 1993; 39: 217-24; Pinguet M. Voluntary death in Japan. Cambridge: Polity Press, 1993. On the significance of these attitudes for the issue of euthanasia see Becker C. Buddhist views of suicide and euthanasia. Philosophy East and West 1990; 40: 543-56.

14 Singer P, Kuhse, H. Should the baby live? Oxford: Oxford University Press, 1985: 105-7.

15 On Japanese attitudes to abortion see LaFleur W. Liquid life: abortion and Buddhism in fapan. Princeton: Princeton University Press, 1992.

16 Stott D. Buddhadharma and contemporary ethics. Religion 1992; 22: 171-81.

17 The Dalai Lama. [letter]. Asiaweek 1985 Nov 1: 73.

18 Sogyal Rinpoche. The Tibetan book of living and dying. London: Rider, 1992: 374.

19 Note, for instance, the reported "growing consensus among the Thai public that euthanasia (passive or active) is morally unjustifiable" in Ratanakul $P$. Thailand: refining cultural values. Hastings Center Report 1990; 20: 27. See also Florida R. Buddhist approaches to euthanasia. Studies in Religion/Sciences Religieuses 1993; 22: 35-47, which is primarily focused on Thailand.

20 Perrett R. Egoism, altruism and intentionalism in Buddhist ethics. Fournal of Indian Philosophy 1987; 15: 71-85.

21 See Pettit P. Consequentialism. In: Singer P, ed. A companion to ethics. Oxford: Basil Blackwell, 1991: 230-40. Note that the Keowns' own definition of "consequentialism" as the view that "the morality of an action turns solely on its consequences" (see reference $1: 267$ ) is probably too crudely restrictive. For a sample of the varieties of consequentialism see Pettit P, ed. Consequentialism. Aldershot: Dartmouth, 1993.

22 See Adams R. Motive utilitarianism. Fournal of Philosophy 1976; 73: 467-81. For the even stronger suggestion that "broad consequentialism" (as opposed to "narrow consequentialism", or utilitarianism) can allow for certain modes of acting having intrinsic value which have to be included in the calculations when seeking to maximise value see Sen A. Evaluator relativity and consequential evaluation. Philosophy and Public Affairs 1983; 12: 113-32. 
23 Majjhima-nikāya 61, 88. Elsewhere Damien Keown resists consequentialist representations of Buddhist ethics in favour of a view of Buddhism as a teleological virtue ethic (see reference 9: ch. 7). However, even there he also readily concedes that consequentialist representations of Buddhist ethics are popular with other Buddhist scholars and find support in both Theravāda and, most especially, Mahāyāna, texts. Personally I find quite unpersuasive Keown's arguments for his own virtue-based representation of Buddhist ethics, but this is a rather large issue which I cannot deal with here.

24 See, for instance, Guenther H. The jewel ornament of liberation by sGam.po.pa. Boulder: Prajna Press, 1971: 24.

25 Conze E. Buddhist scriptures. Harmondsworth: Penguin, 1959: 70. 